\title{
Isolation and Biocidal Activity of Endophytic Fungi de Acrocomia aculeata (Jacq.) Lodd. ex. Mart.
}

Valdivia Rocha Morceli ${ }^{1}$, Simone Maria Neto ${ }^{1}$, Cristina Maria de Souza Motta ${ }^{2}$, Janaina de Cassia Orlandi Sardi ${ }^{1}$, Samuel Araujo de Oliveira ${ }^{3}$, Ana Cristina Jacobowski ${ }^{1}$, Maria Lígia Rodrigues Macedo $^{1 *}$

\author{
${ }^{1}$ Laboratório Purificação de Proteínas e suas Funções Biológicas, Faculdade de Ciências \\ Farmacêuticas, Alimentos e Nutrição, Universidade Federal de Mato Grosso do Sul, 79070- \\ 900, Campo Grande-MS, Brazil. \\ ${ }^{2}$ Laboratório de Micologia, Universidade Federal de Pernambuco, \\ 50670-901, Recife-PE, Brazil. \\ ${ }^{3}$ Laboratório de Ecologia Microbiana e Biotecnologia, Universidade Federal do Ceará, \\ 60020-181, Fortaleza-CE, Brazil.
}

\begin{abstract}
In order to evaluate potential biocidal activities, endophytic fungi present in the leaves of Acrocomia aculeata were isolated and identified in the expectation of finding new strains and new fungal products with pharmacological potential. Fifty fungi were isolated, 25 of which were identified in the genus Fusarium. Of these, eight strains with divergent morphological characteristics had their genre confirmed by sequencing the internal transcribed spacer region (ITS) of the fungal ribosomal DNA (rDNA). The nucleotide sequences obtained were compared with similar sequences on GenBank using the local BLAST NCBI, with a $100 \%$ similarity homology. The eight fungi were identified as Fusarium sp. Ethyl acetate extract from the fungi was subjected to biological tests demonstrating inhibition of bacterial growthand and an important anti-Candida albicans activity.
\end{abstract}

Keywords: Antimicrobial agents, Endophytes fungi, Fusarium,

\section{Introduction}

Acrocomia aculeata, a palm widely distributed in the Brazilian biome of the Cerrado (Ramos et al., 2008), are widely appreciated and used in local cuisine in an artisanal manner due to their nutritional properties. However, research on endophytic fungi present in this plant remains scarce.

Endophytic fungi are responsible for the synthesis of several important compounds in the pharmaceutical and agricultural industry. Its biological active metabolites have potential for several applications, such as antibiotics, antimycotics, antitumor, antimicrobial and immunosuppressants (Kaul et al., 2012).

The recent report by the Food and Drug Administration (FDA) shows that of the $38 \%$ of drugs discovered in natural products, microbes contributed to about 25\% (Calixto, 2019). These discoveries really highlighted the critical role of microorganisms as a sustainable channel for the discovery of new drugs (Toghueo, 2020).

The aim of this study was to isolate and identify the endophytic fungi of $A$. aculeata leaves and to evaluate the potential antimicrobial activities of their secondary metabolites.

\section{Materials and Methods}

2.1 Acromomia aculeata leaves collection Leaves were collected from eight individuals of the A. aculeata in the Cerrado, near Campo Grande, 
Mato Grosso do Sul, Brazil $\left(20^{\circ} 25^{\prime} 24 " \mathrm{~S}\right.$, $\left.54^{\circ} 40^{\prime} 07^{\prime \prime} \mathrm{W}\right)$ in August 2015. The collected material was packed and sealed in sterile plastic bags to avoid environment contamination.

\subsection{Isolation of endophytic fungi}

In a sterile laminar flow chamber, $A$. aculeata leaves was sanitized in commercial detergent $10 \%(15$ minutes), hypochlorite solution $10 \%$ (15 minutes), sterile distilled water (briefly), alcohol 70\% (10 minutes) and washed in distilled water five times. From the last water wash, aliquots $(2 \mathrm{~mL})$ were recovered and applied in PDA (potato dextrose agar) medium plates and treated with antibiotics as aseptic control. The dried leaves were cut aseptically, and fragments $(1 \mathrm{~cm})$ were distributed in PDA malt plates containing gentamicin $(250 \mu \mathrm{g} / \mathrm{mL})$ and chloramphenicol $(100 \mu \mathrm{g} / \mathrm{mL})$, and incubated at 35 ${ }^{\circ} \mathrm{C}$, for 7 days. Then, the isolated fungi colonies were stored at $4{ }^{\circ} \mathrm{C}$ for further analysis (modified from Araújo et al., 2010).

\subsection{Morphological identification}

Morphological identification of fungi at genus level was performed by observing macroscopic aspects (color, appearance, consistency and edges of the colony) from central colony cultivation; and microscopic aspects (vegetative and reproductive structures) by slide culture (Dalmau, 1930; Riddell, 1950) and analysis under a microscope according to specialized literature (Leslie and Summerell, 2008).

\subsection{Molecular identification}

\subsubsection{Genomic DNA extraction}

Genomic DNA from fungal isolates grown on PDA at $25{ }^{\circ} \mathrm{C}$, for 5 days, was extracted using the cetyltrimethylammonium bromide (CTAB) protocol (Warner, 1996). For this, a plug of the fungal mycelium was transferred to $1.5 \mathrm{~mL}$ tubes containing $500 \mu \mathrm{L}$ of CTAB $2 \mathrm{X}$ extraction buffer (2\% CTAB, $1.4 \mathrm{M} \mathrm{NaCl}, 100 \mathrm{mM}$ Tris-HCL pH 8.0 and EDTA 20) preheated at $60{ }^{\circ} \mathrm{C}$. The tubes were homogenized and left in a water bath at $60{ }^{\circ} \mathrm{C}$ for $16 \mathrm{~h}$. After this period, $500 \mu \mathrm{L}$ of chloroform-isoamyl alcohol (24:1; $\mathrm{v} / \mathrm{v})$ was added followed by tube homogenization by inversion. The tubes were centrifuged at $9700 \mathrm{~g}$ for $30 \mathrm{~min}$, and the upper aqueous phase was recovered and transferred to new tubes. To equivalent of $2 / 3$ of the volume collected in the previous step was added $100 \%$ isopopanol and centrifuged at $9700 \mathrm{~g}$ for 10 min and the supernatant discarded. The precipitate was washed with $400 \mu \mathrm{L}$ of ice cold $70 \%$ ethanol and centrifuged at $9700 \mathrm{~g}$ for $10 \mathrm{~min}$, and the supernatant discarded. After the complete evaporation of ethanol, the obtained DNA was eluted in $50 \mu \mathrm{L}$ Tris- $\mathrm{HCl}(10 \mathrm{mM}, \mathrm{pH} 8.0)$ with $20 \mu \mathrm{g} / \mu \mathrm{L}$ RNAse (Sigma-Aldrich, Saint-Louis, MI, USA). Concentrations and qualities of DNA extractions were evaluated by absorbance measurements on a Nanodrop® ND-1000 spectrophotometer (NanoDrop, Wilmington, DE, USA), checked by $0.8 \%$ agarose gel electrophoresis and revealed with SYBR® Safe DNA (Invitrogen, USA).

\subsubsection{Amplification and sequencing of ITS - rDNA regions}

Molecular identification of the fungi was performed by sequencing of the internal transcribed spacer (ITS) regions 1 and 2 , including the $5.8 \mathrm{~S}$ using the primers ITS1 (5'-TCCGTAGGTGAACCTGCGG-3') and ITS4 (5'- TCCTCCGCTTATTGATATGC-3') (White et al., 1990). The polymerase chain reaction (PCR) was performed in a final volume of $50 \mu \mathrm{L}$, containing $20 \mathrm{ng}$ of genomic DNA, $20 \mathrm{mM}$ Tris- $\mathrm{HCl}$ (pH 8.4); $3.0 \mathrm{mM} \mathrm{MgCl} 2 ; 0.2 \mathrm{mM}$ of each dNTP; 0.5 $\mu \mathrm{M}$ of each primer; and 1.0 unit of Taq DNA polymerase (GoTaq, Promega, USA). PCRs were performed on the thermal cycler (Eppendorf Mastercycler® Hamburg, Germany) programmed for an initial denaturation step $\left(3 \mathrm{~min}\right.$ at $\left.94{ }^{\circ} \mathrm{C}\right)$, followed by 35 cycles of $1 \mathrm{~min}$ at $94{ }^{\circ} \mathrm{C}, 1 \mathrm{~min}$ at $52.5{ }^{\circ} \mathrm{C}$ and $1.5 \mathrm{~min}$ at $72{ }^{\circ} \mathrm{C}$. The last cycle was followed by a final extension of $10 \mathrm{~min}$ at $72{ }^{\circ} \mathrm{C}$. The amplicons were analyzed by $1 \%(\mathrm{w} / \mathrm{v})$ agarose gel electrophoresis revealed with SYBR ${ }^{\circledR}$ Safe DNA (Invitrogen, USA). Products were purified using the Wizard® SV Gel and PCR Cleaning System (Promega Corporation, Madison, WI, USA). The concentration of the purified products was checked by measuring the absorbance at $260 \mathrm{~nm}$ on the Nanodrop ${ }^{\circledR}$ ND-1000 spectrophotometer. DNA sequencing was performed by Macrogen Inc., Seoul, Korea using ITS1 and ITS4 starters and the ABI PRISM ${ }^{\circledR}$ BigDye ${ }^{\mathrm{TM}}$ Terminator Cycle Sequencing Kit (Applied Biosystems, CA, USA). The partial sequences provided by Macrogen Inc. were high quality (Phred> 20) and used to generate consensus sequences using the Codon Code Aligner version 6.0.2 program (Codon Code Corp, USA). The nucleotide sequences were deposited at NCBIGenBank.

\subsubsection{Sequence analysis}

The nucleotide sequences were compared to GenBank database of the National Center for National Center for Biotechnology Information (NCBI), through BLAST algorithm. The best score was used to ground the specie identification.

\subsection{Fungal organic extraction}

Those fungi molecularly identified as belonging to genus Fusarium were grown in PDA medium for 10 days. A litter of PD broth were inoculated with 12 fragments $\left(7 \mathrm{~mm}^{2}\right)$ from each fungal isolate and incubated at room temperature for 28 days. After, the 
fermented media were vacuum filtered to separate the mycelium. The filtrate was submitted to liquidliquid extraction with ethyl acetate (EtOAc) 1:1 $(\mathrm{v} / \mathrm{v})$. The aqueous phase was separated and discarded. The organic phase was concentrated by complete solvent evaporation at $45^{\circ} \mathrm{C}$ (Phongpaichit et al., 2007). The final product was diluted in DMSO to a concentration of $100 \mathrm{mg} / \mathrm{mL}$ of EtOAc extracts and up to a maximum of 7\% DMSO (Marcellano et $a l ., 2017)$ and reserved to following assays.

\subsection{Antimicrobial Susceptibility Tests}

The strains challenged were Acinetobacter baumannii (ATCC19606), Enterobacter cloaceae (ATCC81304), Escherichia coli (ATCC 35218), Proteus mirabilis (ATCC 12453), Pseudomonas aeruginosa (ATCC9027), Salmonella enterica (ATCC 51741), Staphylococcus aureus (ATCC 25923), Staphylococcus haemoliyticus (ATCC 29970), Candida albicans (ATCC MYA-2876) and C. tropicalis (ATCC 750). The broth microdilution assay was performed in 96-well microplates according the M07-A10 (CLSI, 2017) and M27-A2 (CLSI, 2008) protocol standard. Briefly, the microorganisms stock was incubated in BHI broth for $24 \mathrm{~h}$ at $37{ }^{\circ} \mathrm{C}$. Subsequently, plated on MHA (bacterial) or SDA (yeast), incubated for $24 \mathrm{~h}$ at 37 ${ }^{\circ} \mathrm{C}$. Sterile $0.9 \%$ saline were inoculated with grown colonies until reaches the $0.5 \mathrm{McF}$ arland turbidity scale, then diluted $(1: 20 ; \mathrm{v} / \mathrm{v})$ in same solution. After microplate inoculation, the bacterial count was of approximately $10^{5} \mathrm{CFU} / \mathrm{mL}$ to bacteria and $10^{3}$ $\mathrm{CFU} / \mathrm{mL}$ to yeast. Chloramphenicol or Amphotericin $\mathrm{B}$ was used as control; 7\% DMSO and saline as growth control. Initially, all samples had their antimicrobial potential evaluated at 10 to bacterial and $40 \mathrm{mg} / \mathrm{mL}$ concentration to yeast. Those that reached $90 \%$ inhibition of bacterial growth, had the minimum inhibitory concentration (MIC) determined through serial dilution from $40 \mathrm{mg} / \mathrm{mL}$ to 0.31 $\mu \mathrm{g} / \mathrm{mL}$.

2.7 Anti-biofilm activity of extract sp. 34 and sp. 51 against Candida albicans

Biofilms were formed in 96-well plates. A $200 \mu \mathrm{L}$ aliquot of a suspension of $1 \times 10^{8}$ cells $/ \mathrm{mL}$ of Candida albicans in $0.9 \%$ saline were added in wells for the initial pre-adhesion for $2 \mathrm{~h}$ at $37^{\circ} \mathrm{C}$. After that time, the saline was removed along with the nonadherent cells. The compounds were diluted in Yeast Nitrogen Base (YNB) with $1 \%$ glucose in concentrations $1 \mathrm{X}$ and $3 \mathrm{X}$ at MIC and left for $24 \mathrm{~h}$ in an oven at $37{ }^{\circ} \mathrm{C}$. After this period, the wells were washed twice with saline to remove the culture medium, extracts and also dead and non-adherent cells. For the formation of mature biofilms were left for $24 \mathrm{~h}$ for formation and then treated for another 24 $h$. Then, the biofilms were plated on BHI plates. The percentage of viable cells was determined based on the survival of comparatively untreated biofilms (Bombarda et al, 2019). Amphotericin B (gold standard) was used as a control and the experiments were carried out in triplicate at three different times.

\subsection{Systemic toxicity in the invertebrate model} G. mellonella larvae.

The test was carried out to assess acute toxicity of the extracts (sp. 31, sp. 34, sp. 51) described by Bombarda et al. (2019). In experiments, 10 larvae were used for each group, weighing between 0.2 to $0.25 \mathrm{~g}$ without signs of melanization. $10 \mu \mathrm{L}$ of the extracts in different concentrations $(100 \mathrm{mg} / \mathrm{mL}, 60$ $\mathrm{mg} / \mathrm{mL}$ and $10 \mathrm{mg} / \mathrm{mL}$ ) were injected into the hemocele of each larva through the last left proleg using a Hamilton syringe (Hamilton Inc, NV, USA). The larvae were incubated and analyzed at intervals for up to $72 \mathrm{~h}$. Larvae without movement or showing high melanization were counted as dead.

\section{Results and discussion}

A total of 50 fungi were isolated, being 25 identified through morphological identified as Fusarium sp. Of these, eight strains with morphological characteristics divergent from those commonly described for Fusarium genus were select and had their peculiar characteristics analyzed. These Fusarium strains were named Sp.5, Sp. 24, Sp.31, Sp.32, Sp.34, Sp.50, Sp.51 and Sp.53. Morphologically, the fungi colonies grown in PDA had pale white, cream, lilac, pink and salmon coloration, the cottony hyphae and sometimes partially immersed in the middle (Figure 1). Those characteristics are determinants for the identification of Fusarium species, which takes into account the colony color, medium pigments, growth velocity, and mycelium appearance (if immersed in the middle, aerial or spars) (Leslie and Summerell, 2008).

In the microscopical analysis, it was observed: shape and size of the conidia (macro or microconidia); aseptate or septate conidia, and its quantities (if applied); presence or absence of chlamydospores; presence or absence of the phialides; the phialides shape and size, if simple, compounded or spiraled (Booth, 1971; Leslie and Sumerell, 2008). The main findings in the fungi here analyzed was show in Figure 2, being salient the large presence of trap hyphae (coileds), as indicated by the letter $\mathrm{G}$, which are hygrophilous hyphae, specialized in killing nematodes or phytopathogenic fungi. In Table 1, the measurements of the reproduction structures were presented, according to the standard procedure for Fusarium identification (Leslie and Sumerell, 2008; Sumerell and Leslie, 2011; Sumerell, 2019) 
At molecular level, the isolated fungi were identified by comparing their nucleotide sequences to those deposited in GenBank database of the National Center for National Center for Biotechnology Information (NCBI), through BLAST algorithm. All isolated fungi matched with $100 \%$ similarity, $100 \%$ cover and 0.0 e-value to Fusarium sp. However, due to the high conservation of ITS1 and ITS4 sequences into Fusarium species, it was not possible to identify the specie of which isolated with precision, only at the genus level was ratified. The eight sequences were deposited in the NCBI-GenBank under accession number indicated in table 2.

Although few studies about endophytic fungi of $A$. aculeate had been published, the genus Fusarium is always present in Arecaceae family (Lodge et al., 1996). Song et al, (2015), investigated the presence of endophytic fungi in 10 species of healthy Arecaceae and found 10 different fungal genera (Cladosporium, Phialophora, Pestalotiopsis, Phoma, Phomopsis, Nigrospora, Xylaria, Fusarium, Colletotrichum and Rhizoctonia), and other 20 fungi isolated belonging to mycelia sterilia fungus. Morales-Lizcano et al. (2017) evaluated microbial diversity in coconut palms (Cocos nucifera L.) with symptoms of fungal diseases and without any symptoms and the Fusarium species was present in both populations. Like demonstrated by Tibpromma et al (2018) that reported the presence of 22 endophytic fungi isolated in Mycelia sterilia, one unidentified and 13 mitosporic fungi including Cladosporium sp., Colletotrichum gloeosporioides, Corynespora-like, Fusarium sp., Guignardia cocaicola, Paecilomyces sp. Pestalotiopsis sp., Phialophora sp., Phoma sp., Phoma-like sp.
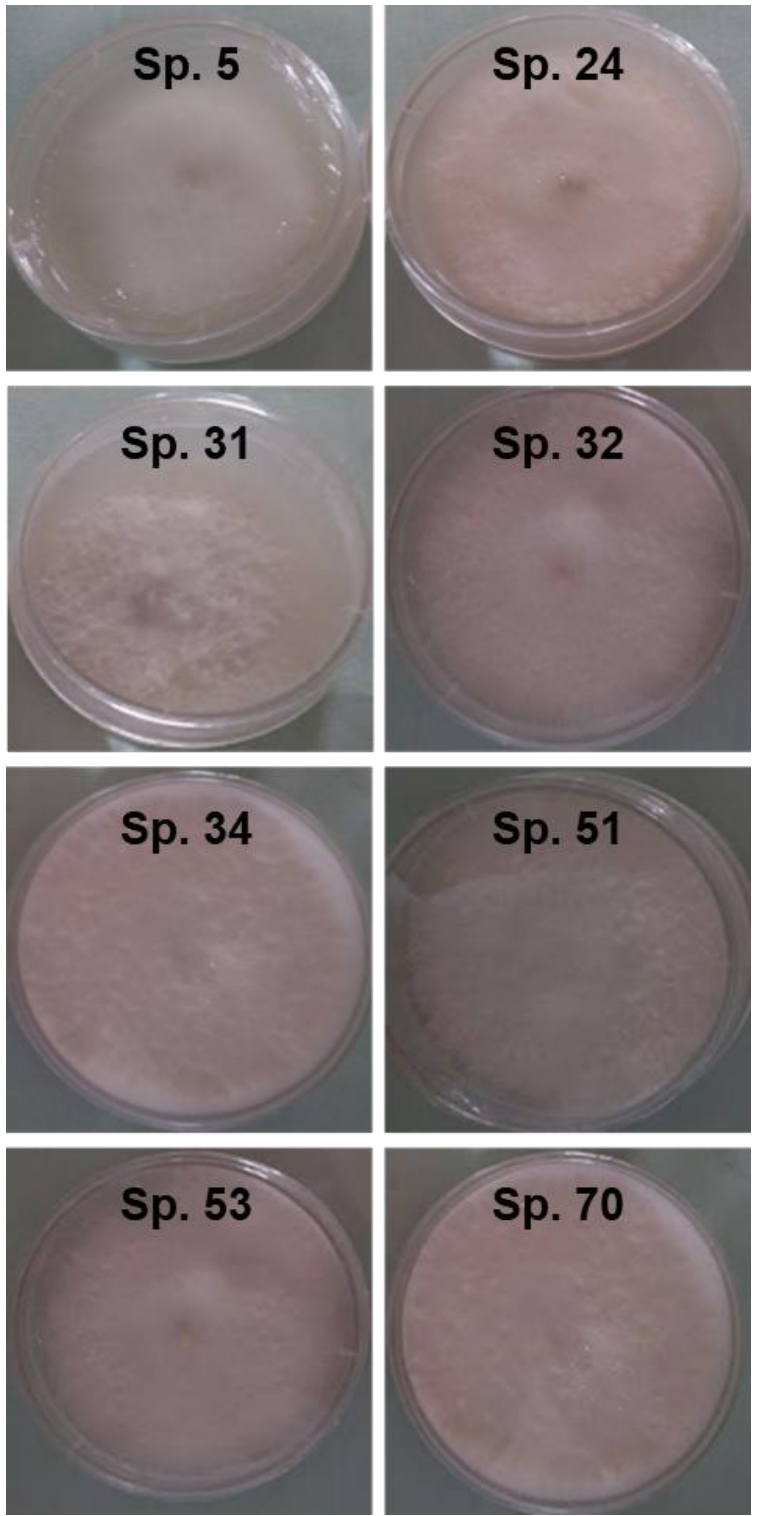

Figure 1. Morphology of isolated fungi colonies grown in Potato dextrose agar plates for 10 days at room temperature. 
ISSN 2455-6378

Fusarium sp. 5

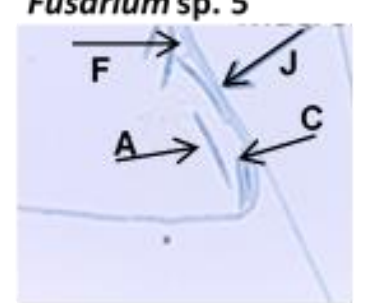

Fusarium sp. 31

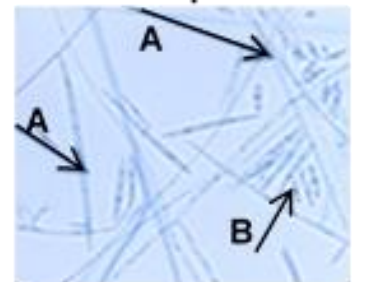

Fusarium sp. 34

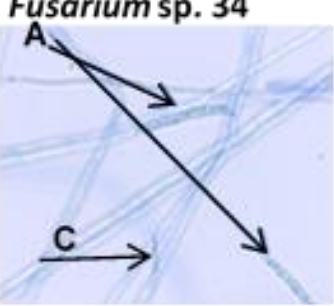

Fusarium sp. 53

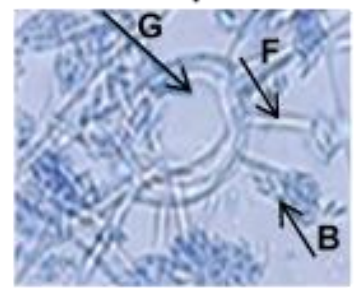

Fusarium sp. 24

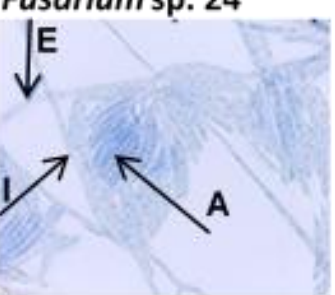

Fusarium sp. 32

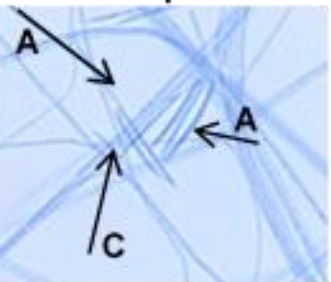

Fusarium sp. 51

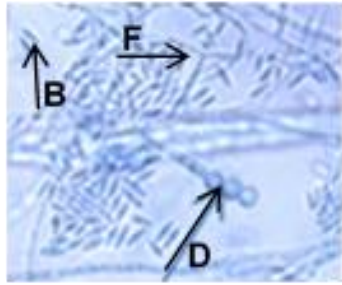

Fusarium sp. 70

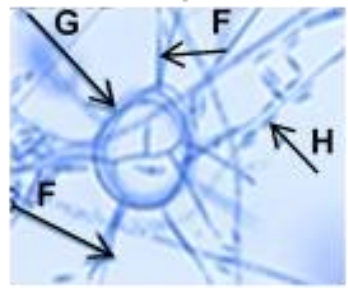

Figure. 2. Microscopic features of Fusarium on the Potato dextrose agar media. A: Macroconidia; B: Microconidia; C: Mesoconidia; D: Chlamydospores; E: Sporodoquia set F: Phialides; G: Coiled hypha; H: Microconidia chain; I: Sporodoquia; J: Hifas.

The evolution between plants and fungi has produced modified and stored chemical structures that form an important and unexplored reservoir that is believed involved in the protection and communication between host plants (Farrar et al., 2014; Yadav, 2019).

With this thought, this study evaluated the antimicrobial, and anticancer potential of compounds found into EtOAc extracts of isolated endophyte fungi of A. aculeata of the genus Fusarium. In a preliminary assay, the isolates sp. 31 , sp. 34 e sp. 51 showed the best antimicrobial results, being able to control the bacterial growth of almost all challenged bacterial strains. Then, these isoletes had their MIC determined (Tab. 3).
Table 1. Characteristics and measurements of fungal reproductive structures.

\begin{tabular}{|c|c|c|}
\hline & \multicolumn{2}{|c|}{ Macroconidia } \\
\hline Species & Size $(\mu \mathrm{m} / \mu \mathrm{m})$ & Shape \\
\hline Sp. 5 & $81 / 162$ & Straight, Curved \\
\hline Sp. 24 & $32.4 / 43.2$ & Curved \\
\hline Sp. 31 & $27 / 86.4$ & Straight \\
\hline Sp. 32 & $27 / 81$ & Curved \\
\hline Sp. 34 & $78 / 98$ & Straight \\
\hline Sp. 51 & $27 / 75$ & Curved \\
\hline Sp. 53 & $40.5 / 32.4$ & Straight \\
\hline \multirow[t]{2}{*}{ Sp. 70} & $30 / 5.3$ & Straight \\
\hline & \multicolumn{2}{|c|}{ Microconidia } \\
\hline Species & Size $(\mu \mathrm{m} / \mu \mathrm{m})$ & Shape \\
\hline Sp. 5 & $8.1 / 13.5$ & Straight \\
\hline Sp. 24 & Absent & Absent \\
\hline Sp. 31 & $7 / 10.5$ & Straight \\
\hline Sp. 32 & $15 / 9$ & Straight \\
\hline Sp. 34 & $11.5 / 8.3$ & Straight \\
\hline Sp. 51 & $18.9 / 19.8$ & Straight \\
\hline Sp. 53 & $8.1 / 13.5$ & Ovals \\
\hline \multirow[t]{2}{*}{ Sp. 70} & $8.0 / 11$ & Straight \\
\hline & Sporodochium & Phialides \\
\hline Sp. 5 & Absent & Monophialides \\
\hline Sp. 24 & Present & Monophialides \\
\hline Sp. 31 & Absent & Monophialides \\
\hline Sp. 32 & Absent & Polyphialides \\
\hline Sp. 34 & Absent & Monophialides \\
\hline Sp. 51 & Absent & Polyphialides, verticiled \\
\hline Sp. 53 & Absent & Monophialides \\
\hline Sp. 70 & Absent & Polyphialides \\
\hline
\end{tabular}

Table 2. Accession numbers of Fusarium sequences deposited in the NCBI-GenBank.

\begin{tabular}{lc}
\hline Isolated & GenBank accession \\
\hline Fusarium sp. 5 & MN428023 \\
Fusarium sp. 24 & MN428024 \\
Fusarium sp. 31 & MN428025 \\
Fusarium sp. 32 & MN428026 \\
Fusarium sp. 34 & MN428027 \\
Fusarium sp. 51 & MN428028 \\
Fusarium sp. 53 & MN428029 \\
Fusarium sp. 70 & MN428230 \\
\hline
\end{tabular}

The EtOAc extract of Fusarium sp.31 inhibited the growth of all bacterial strains, with the exception of $A$. baumannii and $P$. mirabillis, in which caused an extension of the lag phase of bacterium growth. With the EtOAc extract of Fusarium sp. 34, it was possible to achieve MIC to all bacterial and yeast strains in the tested concentrations. Indeed, sp. 34 extract showed the lowest MICS among tested extracts for A. baumannii (5 mg/mL), E. cloacae ( 5 $\mathrm{mg} / \mathrm{mL})$ and $E$. coli $(2.5 \mathrm{mg} / \mathrm{mL})$. In its turn, the EtOAc extract of Fusarium sp. 51 inhibited the growth of six of the bacterial and two yeast strains 
used in this assay, but in $A$. baumannii and $E$. cloacae it only extended the lag phase.

The mechanism inherent to the extension of the lag phase was evaluated in the kinetic of growth curve of bacteria in presence of $\beta$-lactam antibiotics (Li et al., 2016), being observed the delay time extended with the increase in the concentrations of antibiotics as a response to the caused stress. In the current study, to the majority of bacterial strains in which MIC cannot be reached, the lag phase always was extended between 10 to 12 hours suggesting dose-dependency. However, this data can only be propriely determinated in further studies, after the purification of active molecule(s).

Table 3. Minimum inhibitory concentrations de EtOAc extracts of isolated Fusarium species. G-: Gram-negative; G+: Grampositive; EtOAc: ethyl acetate.

\begin{tabular}{|c|c|c|c|c|c|}
\hline & & \multicolumn{4}{|c|}{$\mathrm{MIC}(\mathrm{mg} / \mathrm{mL})$} \\
\hline Microorganisms & ATCC & $\begin{array}{l}\text { Gram } \\
\text { Type }\end{array}$ & $\begin{array}{l}\text { sp. } \\
31\end{array}$ & $\begin{array}{l}\text { sp. } \\
34\end{array}$ & $\begin{array}{l}\text { sp. } \\
51\end{array}$ \\
\hline A. baumannii & 19606 & G- & $>10$ & 5 & $>10$ \\
\hline E. coli & 35218 & G- & 10 & 2.5 & 5 \\
\hline E. cloacae & 81304 & G- & 10 & 5 & $>10$ \\
\hline P. aeruginosa & 9027 & G- & 9 & 9 & 8 \\
\hline P. mirabillis & 2453 & G- & $>10$ & 10 & $>10$ \\
\hline S. enterica & 51741 & G- & 10 & 10 & 10 \\
\hline S. aureus & 80958 & $\mathrm{G}+$ & 10 & 10 & 10 \\
\hline S. haemoliyticus & 29970 & G+ & 10 & 10 & $>10$ \\
\hline C. albicans & 2876 & - & $>40$ & 20 & 40 \\
\hline C. tropicalis & 750 & - & $>40$ & 20 & 40 \\
\hline
\end{tabular}

The current work evaluated of biocidal potencial of fungi metabolic extracts, and the results found are similar to those recurrently observed in the literature. Here, the most susceptive bacterial strain to Fusarium extracts was E. coli, with MIC values between 2.5 and $5 \mathrm{mg} / \mathrm{mL}$. Marcellano et al. (2017) observed similar susceptibility of $E$. coli strain to EtOAc extract of endophytic fungi Cinnamomum mercadoi, with a MIC of $4.4 \mathrm{mg} / \mathrm{mL}$. This extract also showed moderate antibacterial activity against the other bacterial strains with $10 \mathrm{mg} / \mathrm{mL}$.

Kyekyeku et al (2017) showed antibacterial activity of EtOAc extract of $F$. solani against $S$. aureus, Acinetobacter sp., E. coli and B. subtillis, and found that the crude extract had the same yield as the compounds obtained with MICS of equally low values. Zhang et al. (2016) reported that a methanolic extract of the endophyte Fusarium sp. JY2, isolated from Honeysuckle (Lonicera caprifolium), was efficient in to control the growth the $P$. aeruginosa with $\mathrm{MIC}$ and $\mathrm{MBC}$ values of $0.2625 \mathrm{mg} / \mathrm{mL}$ and $1.05 \mathrm{mg} / \mathrm{mL}$, respectively. This extract exhibited a broad spectrum of action toward both Gram-negative and Gram-positive bacteria. Obtained saponins from extracts of $F$. oxysporum PN8 and A. niger PN17 showed moderate to strong inhibitory activity against Gram-positive and Gramnegative bacteria, being observed MICs from 1.6 to $3.2 \mathrm{mg} / \mathrm{mL}$ (Jin et al., 2017).

As described in the literature, Fusarium species are known to producers secondary metabolics with a broad spectrum of antimicrobial action, like betalactam antibiotics, such as penecillins and cephalosporins (Kuck et al., 2014). As well, Ibrahim et al. (2016) demonstrated the antimicrobial and cytotoxic activity of fusarithioamide A, produced by the endophytic fungus $F$. chlamydosporium isolated from the leaves of Anvillea garcini showed a potent activity against $B$. cereus, S. aureus, E. coli and Candida albicans with MICs values of 3.1, 4.4, 6.9 and $2.6 \mu \mathrm{g} / \mathrm{mL}$ respectively.

Another endophytic fungus Fusarium sp., isolated from the invasive cactus Opuntia dilleniid, produced the antimicrobial secondary metabolite equisetin (Ratnaweera et al., 2015). In addition, sanguinarine is an antimicrobial benzylisoquinoline alkaloid isolated from the endophytic fungal strain $F$. proliferatum found in the poppy Macleaya cordata (Wang et al., 2014). Likewise, Ibrahim et al. (2018) found the Fusaripeptide A, a new antifungal and antimalarial cyclodepsipeptide from the endophytic fungus Fusarium sp. of Mentha longifolia L. (Labiatae) plant. In addition, a biofilm study was performed with Candida albicans strain with extracts sp. 34 and sp. 51. The results showed that these extracts were able to inhibit biofilm formation as well as having an action on mature biofilms, as seen in Figure 3. Our results demonstrated a reduction in the viability of the biofilm and are in line with those obtained by Chatterjee et al. (2020).

In addition, acute toxicity tests on Galleria mellonella alternative model larvae were performed. As seen in Figure 4, the larvae treated with different concentrations of sp. 31 , sp. 34 and sp. 51 showed low toxicity, maintaining viability around $70 \%$ for the highest concentration. Thus, demonstrating the low toxicity of these extracts. 


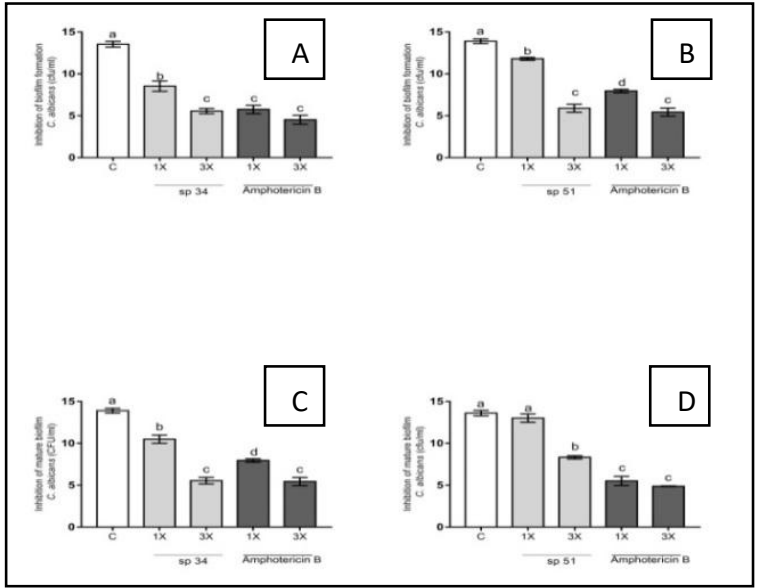

Figure 3. Quantitative analysis (CFU determination $/ \mathrm{mL}$ ) of inhibitory effects (mean \pm SD) of sp. 34 and sp. 51, amphotericin $\mathrm{B}$ in $(\mathrm{A}, \mathrm{B})$ Candida albicans biofilm and (C,D) mature biofilm Candida albicans at concentrations $1 \mathrm{X}$ MIC and $3 \mathrm{X}$ MIC $(\mathrm{p}<0.05)$ ANOVA with Tukey's post-test.

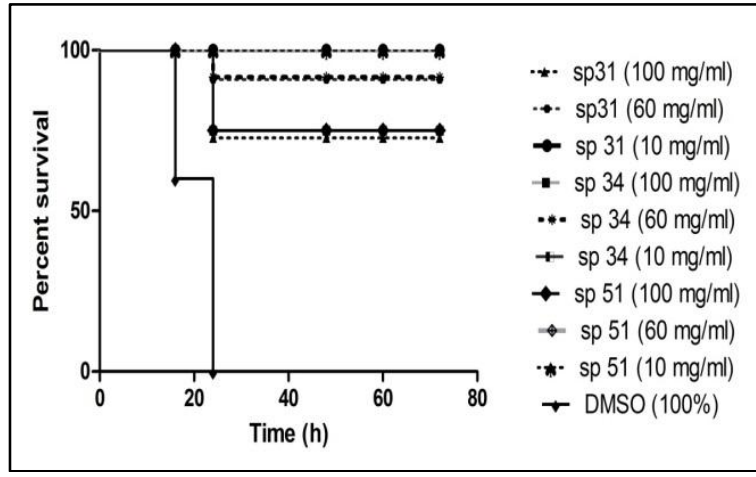

Figure 4. Percentage survival over time of G. mellonella larvae injected with sp. 31 , sp. 34 and sp. 51 at concentrations 100 $\mathrm{mg} / \mathrm{mL}, 60 \mathrm{mg} / \mathrm{mL}$ and $10 \mathrm{mg} / \mathrm{mL}$.

\section{Conclusion}

At the end of this study we concluded that the endophytic fungi present in the A. aculeata species (sp. 31, sp. 34 and sp. 51), have potential as producers of secondary metabolites with antimicrobial action. These fungal endophytes of $A$. aculeata could be an appropriate source to produce antibacterial and antifungal agents. It will be interesting to investigate further the fungi found in this plant. As well as their, antioxidant and anticancer capacities among others as we can see in several species of the genus Fusarium.

\section{Acknowledgments}

Authors thank the Brazilian development agencies CNPq, FUNDECT. The present work was carried out with support from the Federal University of Mato
Grosso do Sul - UFMS / MEC - Brazil with the support of the Coordination for the Improvement of Higher Education Personnel - Brazil (Capes) Financing Code 001".

\section{References}

[1] Araújo, W, Lacava, P, Marcon, J, Lima, A, Sobral, J, Pizzirani-Kleiner, A and Azevedo, J, Guia prático: Isolamento e caracterização de microrganismos endofíticos. Cop Luiz de Queiroz, Piracicaba, 167p. Vol, (2010).

[2] Bombarda, G, Sardi, J, Rosalen, P, Lazarini, J, Paganini, E, Regasini, L, Anti-adhesive and antibiofilm activity of NC-E08. In vitro and in vivo study using Galleria mellonella infection model. Revista dos Trabalhos de Iniciação Científica da UNICAMP. 26 (2019).

[3] Booth, C, The genus Fusarium. Pub. Commonwealth Agricultural Bureaux, (1971).

[4] Calixto, J, The role of natural products in modern drug discovery. Anais da Academia Brasileira de Ciencias. Vol 91 Suppl 3 e20190105 (2019).

[5] Chatterjee, S, Ghosh, R, Mandal N, Inhibition of biofilm - and hyphal - development, two virulent features of Candida albicans by secondary metabolites of na endophytic fungus Alternaria tenuissima having broad spectrum antifungal potential. 232 (2020).

[6] CLSI, Reference Method for Dilution Tests in Broth for Determining the Sensitivity of Yeasts to Antifungal Therapy: Standard Approved Second Edition. CLSI standard M27A2. Wayne, PA: Clinical and Laboratory Standards Institute, (2008).

[7] CLSI, Reference method for broth dilution antifungal susceptibility testing of yeasts. 4th ed. CLSI standard M27. Wayne, PA: Clinical and Laboratory Standards Institute, (2017).

[8] Dalmau, L, Observations on mycologic technique with particular reference to pathogenic fungi. (1930).

[9] Farrar, K; Bryant, D and Cope-Selby, N. Understanding and engineering beneficial plantmicrobe interactions: plant growth promotion in energy crops. Plant Biotechnology Journal. Vol 12(9): 1193-1206, (2014).

[10] Ibrahim, S; Elkhayat, E; Mohamed, G; Fat'hi, S and Ross, A. Fusarithioamide A, a new antimicrobial and cytotoxic benzamide derivative from the endophytic fungus Fusarium chlamydosporium. Biochemical and Biophysical Research Communications. Vol 479(2): 211-216, (2016). 
[11] Ibrahim, S; Abdallah, H; Elkhayat, E; Al Musayeib, N; Asfour, H; Zayed, $\mathrm{M}$ and Mohamed, G, Fusaripeptide A: new antifungal and anti-malarial cyclodepsipeptide from the endophytic fungus Fusarium $s p$. Journal of Asian Natural Products Research. Vol 20(1): 75$85,(2018)$.

[12] Jin, Z, Gao, L, Zhang, L, Liu, T, Yu, F, Zhang, Z, Guo, Q and Wang, B, Antimicrobial activity of saponins produced by two novel endophytic fungi from Panax notoginseng. Natural Product Research. Vol 31(22): 2700-2703, (2017).

[13] Kaul, S, Gupta, S, Ahmed, M, Dhar, M, Endophytic fungi from medicinal plants: a treasure hunt for bioactive metabolites. Phytochem Rev 11, 487-505 (2012).

[14] Kuck, U, Bloemendal, S and Teichert, I, Putting fungi to work: harvesting a cornucopia of drugs, toxins, and antibiotics. PLoS Pathogens. Vol 10(3): e1003950, (2014).

[15] Kyekyeku, J, Kusari, S, Adosraku, R, Bullach, A, Golz, C, Strohmann, C and Spiteller, M, Antibacterial secondary metabolites from an endophytic fungus, Fusarium solani JK10. Fitoterapia. Vol 119 108-114, (2017).

[16] Leslie, J, Summerell, B, The Fusarium laboratory manual. Vol, John Wiley \& Sons (2008).

[17] Li, B, Qiu, Y, Shi, $\mathrm{H}$ and Yin, H, The importance of lag time extension in determining bacterial resistance to antibiotics. Analyst. Vol 141(10): 3059-3067, (2016).

[18] Lodge, D, Fisher, P, Sutton, B, Endophytic fungi of Manilkara bidentata leaves in Puerto Rico. Mycologia. Vol 88 (5): 733-738, (1996).

[19] Marcellano, J, Collanto, A and Fuentes, R, Antibacterial activity of endophytic fungi isolated from the Bark of Cinnamomum mercadoi. Pharmacognosy Journal. Vol 9 (3) (2017).

[20] Morales-Lizcano, N, Hasan, A, To, H, Lekadou, T, Copeland J, Wang, P, Diallo, H, Konan, J, Yoshioka, K, Moeder, W, Scott, J, Rosete, Y, Microbial diversity in leaves, trunk and rhizosphere of coconut palms (Cocos nucifera L.) associated with the coconut lethal yellowing phytoplasma in Grand-Lahou, Côte d'Ivoire. African Journal of Biotechnology, Vol 16 (27): 1534-1550, (2017).

[21] Phongpaichit, S, Nikom, J, Rungjindamai, N, Sakayaroj, J, Hutadilok-Towatana, N, Rukachaisirikul, Vand Kirtikara, K, Biological activities of extracts from endophytic fungi isolated from Garcinia plants. FEMS
Immunology and Medical Microbiology. Vol 51 (3): 517-525 (2007).

[22] Ramos, M, Ramos-Filho, M, Hiane, P, BragaNeto, J, Siqueira, E, Qualidade nutricional da polpa da bocaiuva Acrocomia aculeata (Jacq.) Lodd. Ciência e Tecnologia de Alimentos, 28: 90-94 (2008).

[23] Ratnaweera, P, de Silva, E, Williams, D, Andersen, R, Antimicrobial activities of endophytic fungi obtained from the arid zone invasive plant Opuntia dillenii and the isolation of equisetin, from endophytic Fusarium $s p$. BMC Complementary and Alternative Medicine. Vol 15(220), (2015).

[24] Riddell, R, Permanent stained mycological preparations obtained by slide culture. Mycologia. Vol 42 (2): 265-270 (1950).

[25] Song, J, Wattanachai, P, Kasem, S, Biological activity of endophytic fungi associated with palm trees. Journal of Agricultural Technology. Vol 11 (2): 567-579, (2015).

[26] Summerell, B, Leslie, J, Fifty years of Fusarium: how could nine species have ever been enough? Fungal Diversity. Vol 50 (1): 135, (2011).

[27] Summerell, B, Resolving Fusarium: Current Status of the Genus. Annual Review of Phytopathology. Vol 57: 323-339, (2019).

[28] Tibpromma S, Hyde K, Bhat J, Mortimer P, Xu J, Promputtha, Itthayakorn, Doilom M, Yang, J, Tang, A, Kurunarathna, S, Identification of endophytic fungi from leaves of Pandanaceae based on their morphotypes and DNA sequences data from Southern Thailand. Mycokeys, 33: 2667, (2018).

[29] Toghueo, R, Bioprospecting endophytic fungi from Fusarium genus as sources of bioactive metabolites. Mycology. Vol 1-21 (2020).

[30] Wang, X; Min, C; Ge, M and Zuo, R, An endophytic sanguinarine-producing fungus from Macleaya cordata, Fusarium proliferatum BLH51. Current Microbiology. Vol 68(3): 336341, (2014).

[31] Warner, S, Genomic DNA isolation and lambda library construction. John Wiley \& Sons Ltd: Chichester, UK, pp. 51-53 (1996).

[32] White, T, Bruns, T, Lee, S, Taylor, J, Amplification and direct sequencing of fungal ribosomal RNA genes for phylogenetics. PCR protocols: a guide to methods and applications. Vol 18 (1): 315-322 (1990).

[33] Yadav, N, Singh, S, Mishra, S and Gupta, A, Recent advancement in white biotechnology through fungi - Vol 3: Perspective for 
Sustainable Environments. Springer Nature, (2019).

[34] Zhang, H, Sun, X, Xu, C, Antimicrobial activity of endophytic fungus Fusarium sp. isolated from medicinal honeysuckle plant. Archives of Biological Sciences. Vol 68(1): 25-30, (2016). 